\title{
OonOMIC
}

ljaz Uddin

\section{Impact of Benazir Income Support Program (BISP) on consumption, health and education}

\section{KEYWORDS}

\section{Benazir Income Support Program;}

consumption;

health;

education;

Pakistan

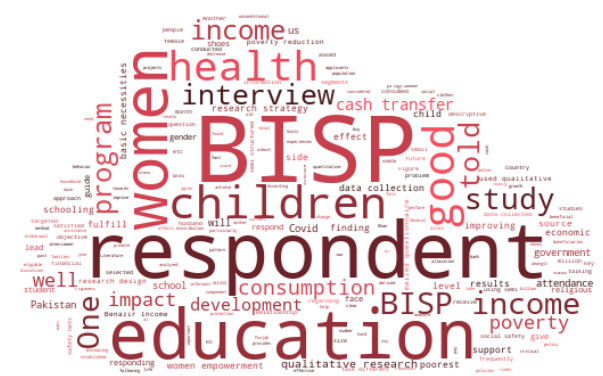

Word Cloud Generated by:

https://wordscloud.pythonanywhere.com/

\section{ABSTRACT}

Introduction. Benazir Income Support Program (BISP) is one of such efforts promulgated by the Government of Pakistan (GoP) in July 2008, as a premier national safety net initiative aimed at eradicating extreme and chronic poverty in the country. The main aim of this empirical study to examined the impact of BISP on consumption, education and health in case study of district Swat Pakistan.

Methodology. This study used the qualitative research strategy because qualitative research strategy provided a variety of opportunities in identifying a problem. The data were collected through key informant interviews and mailed questionnaires. Interviews were conducted face to face using a semi-structured interview guide and as well a mail questionnaire.

Results. The following respondents were well-acknowledged from the situation Covid-19 and have better knowledge about the BISP as a source of income. A total of 4 interviews were conducted from the targeted respondents using a semi-structured interview guide. And sent the mailed questionnaire to 45 respondents, only 7 respondents are replied.

Conclusion. The main aim of this empirical study is to examine the Impact of Benazir income support program (BISP) on consumption, health and education during the COVID 19 pandemic. The finding reveled that BISP have positive effect on consumption, health and education. This empirical study has several recommendations based on research findings; (1) the government should pay the BISP income on monthly basis. (2) The government should increase the BISP income.

Uddin, I. (2021). Impact of Benazir Income Support Program (BISP) on consumption, health and education. Economic consultant, 36 (4), 42-50. doi: 10.46224/ecoc.2021.4.5 


\section{INTRODUCTION}

Cocial protection programs are considered as important tools achieving the Millennium Development Goals (MDGs), and they are promoted as important segments for global poverty reduction policies [1]. The Benazir Income Support program (BISP) was established in July 2008. It is poverty decrease program run by federal government of Pakistan. In 2016 BISP distributed Rs. 90 billion (\$900 million) amongst 5.4 million peoples [2]. The key objective of this program, firstly, to developed financial capability amongst the poor people. Secondly, to promote low income groups, and decrease poverty as well as equal distribution of wealth [3].

The main piece of the program is that it evaluates the appropriateness of the applicants established on a number of multidimensional measures. The information is centered on people's socioeconomic status such as stock ownerships, worth of assets, land holdings, child's education status, toilet facilities, types of housing and house size. Conferring the government reports the data insurances approximately $85 \%$ of the total population eligible to receive the cash transfer. The eligible applicants can then retrieve their amount through an ATM cash withdrawal at allocated sites throughout Pakistan. Services like Easy paisa and bank withdrawal can also be used [4].

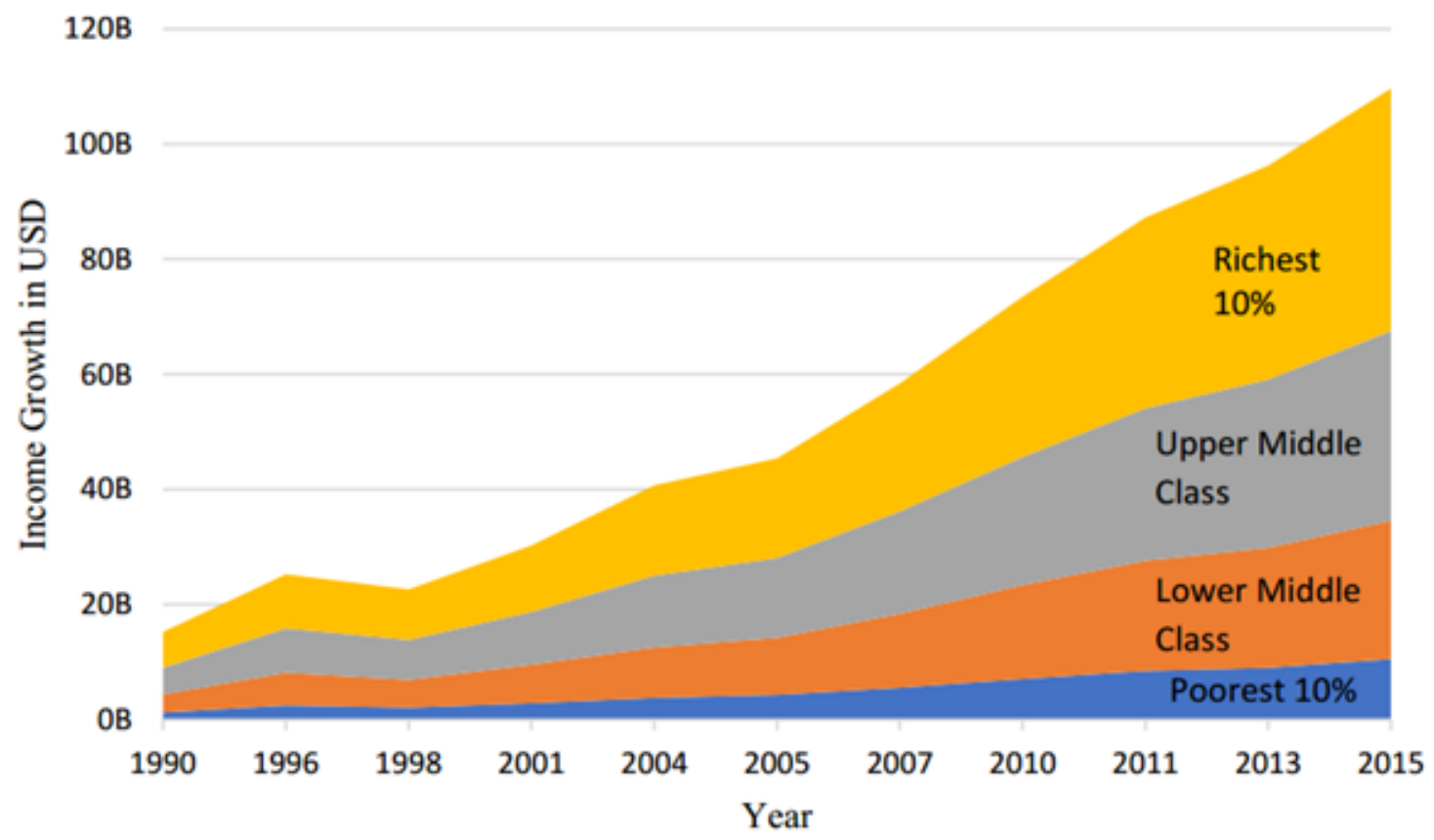

Figure 1 Income distribution in Pakistan. Source: Khan [5]

The figurer 1, revels that a very small change in the size of income of the poorest segments of the population in the past two decades. The BISP is particularly targeted towards such segments to pull them out of chronic poverty through an income redistributive effect. While Figure 2, revels that The annual allocation for BISP from GoP has risen about 161\% between 2014 and 2018. However, there has been a marginal decline in the direct cash transfer between 2017 and 2018, of about 5 Billion Rupees. 


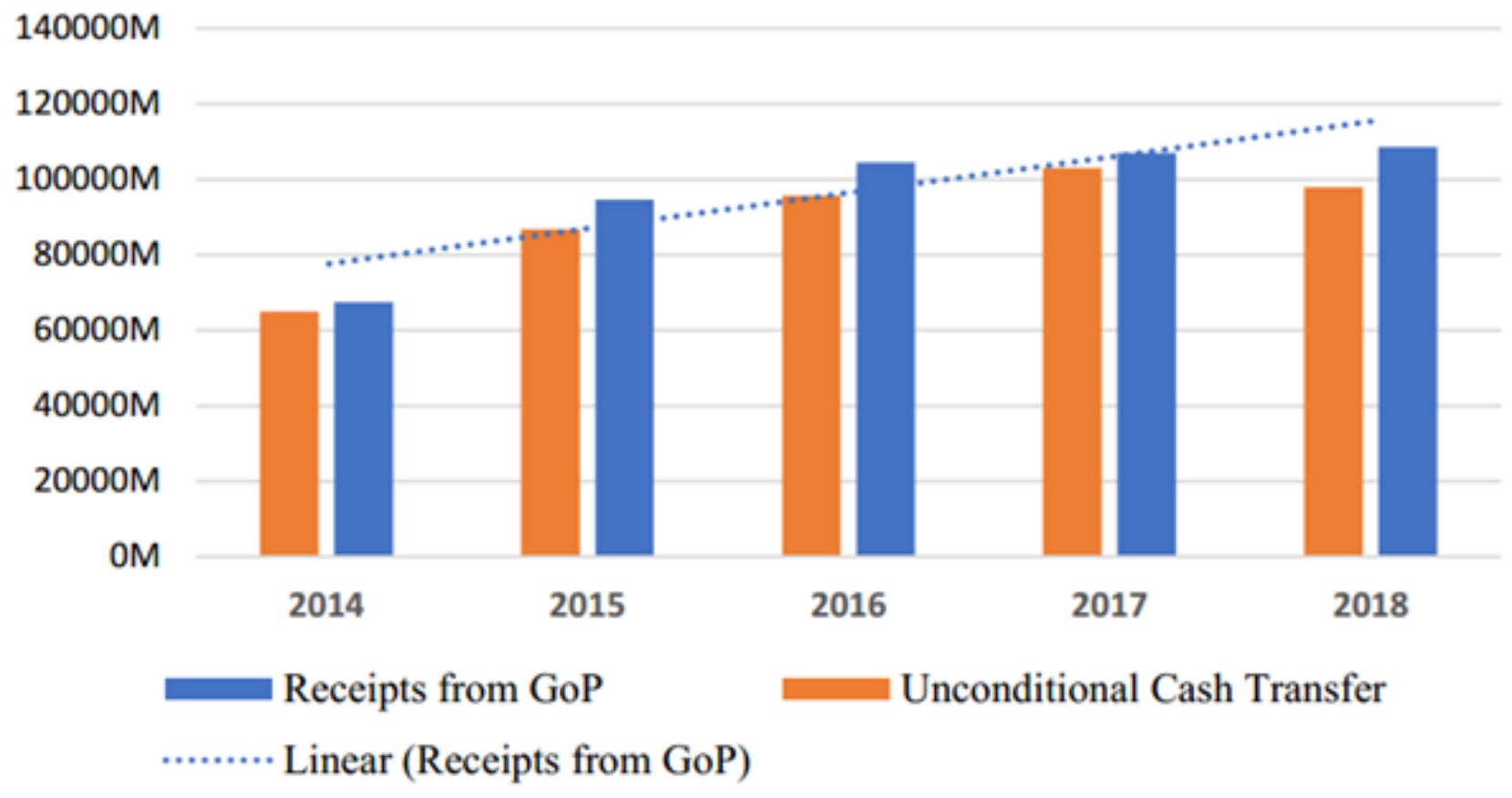

Figure 2 Change in BISP allocation and Cash transfer. Source: Khan, [5]

The BISP is a crucial component of social safety nets that focuses on reducing poverty among women and improving their living standards by giving unconditional cash assistance to the poorest women. According to the BISP, 5.7 million families will be active beneficiaries through 2016. [6; 7] examined rural women empowerment through social protection programs. A case of Benazir income support programme in Punjab, Pakistan This quantitative research was conducted in two districts of Punjab randomly selected out of 36 using face-to-face interviews with a sample size of 160 women beneficiaries of BISP. Most of the respondents were strongly agree (65\%) and agree (95\%) that the assistance should be more than Rs.5000/ month or Rs.10000/month. Similarly, $69.4 \%$ and $71.3 \%$ of respondents agreed that female adults should take household decision and children should attend school regardless of gender. Women's empowerment is seen as a critical component of poverty reduction and development interventions that promote economic development and good governance (World Bank [8; 9] found that the mother's health and education, which leads to a reduction in child mortality and household economic well-being, ensuring income stability.

\section{LITERATURE REVIEW}

Tehmeena et al. [10] worked on welfare impact of Benazir Income Support Program's (BISP) unconditional cash transfers on women empowerment. The study observed that BISP led to improve socio-economic wellbeing of the beneficiary women. Waqas and Torre [11] analyzed social safety nets in the development of a welfare system in Pakistan. They found that social safety nets in a lower middle income country such as Pakistan are considered an 
effective measure for fighting poverty and improving education and health. There is strong evidence that economic growth leads to poverty reduction. Many cross country and crossregional studies (e.g. Besley and Burgess [12]; Dollar and Kraay [8]; Ravallion and Chen [13]) support this assertion. One, then, naturally wonders what the need of cash transfers, or direct redistribution, is. The justification for cash transfers comes from the fact that benefits of the growth do not accrue to everyone particularly the poorest.

On the other hand, cash transfers, through effective targeting, may reach the poorest in a more beneficial way (Fiszbein et al. [14], Yu \& Wang [15]). Poverty is firmly ingrained in many developing countries, and women are disproportionately concentrated on the country's poorest outskirts. Despite the fact that overall poverty reduction remains a struggle for policymakers, improving women's financial well-being necessitates extensive gender evaluations of proposed programmes to eliminate impediments that may perpetuate women's poverty. Several papers, including Narayan-Parker's [16] essential guide for the inclusion of women's empowerment in development policy, propose varied criteria for incorporating gender in the planning phase of development projects to equalise development advantages for men and women.

The literature, on the other hand, suggests that programmes aimed solely at improving women's financial problems do not achieve their goals. Even if they are helped by the state or ODA agencies to start their own small or medium-sized businesses, women frequently accept subordinate jobs. They frequently perform routine tasks in the workplace [17].

Although each institution/stakeholder has its own objectives, the state plays a critical role in empowering women at the grassroots level by beginning various programs/projects and enacting gender-sensitive policies/legislation [18]. According to Gary's [19] "unitary model of family economics" their longer lives and increasing divorce rates more frequently place women in leadership positions in their families. Women in these age brackets are mostly perceived as unsuitable for employment or entrepreneurial activities in Pakistani society [20].

\section{METHODOLOGY}

\section{Research Strategy}

In order to achieve the desired objectives, a qualitative research strategy was used. The qualitative research strategy was used because qualitative research strategy provided a variety of opportunities in identifying a problem. The qualitative research method is very useful because it can help us to better understand behaviors and perceptions. It provides us a clear understanding of our problem or topic. With the help of a qualitative research strategy, a lot of information has been gathered from a very small number of respondents due to its flexible and open-ended structure which allowed the respondents to clearly explain life experiences. 


\section{Research Design}

The research design for this study was descriptive. The descriptive research design was selected because it provides a unique means of data collection in the form of studying life experiences. The descriptive research designs require a particular form of data collection which involves observing and describing the behavior of the subject under study.

\section{Units of Data Collection}

The units of data collection were the targeted respondents relevant to the field of this study. The following respondents were selected for interviews because they have rich information regarding the study. The following respondents were well-acknowledged from the situation Covid-19 and have better knowledge about the BISP as a source of income. A total of 4 interviews were conducted from the targeted respondents using a semi-structured interview guide. And sent the mailed questionnaire to 45 respondents, only 7 respondents are replied.

\section{Methods of Data Collection}

The data were collected through key informant interviews and mailed questionnaires. Interviews were conducted face to face using a semi-structured interview guide and as well a mail questionnaire.

\section{FINDINGS AND DISCUSSIONS}

The findings and results were briefly derived from data collected through conducting key informant interviews using a semi-structured interview guide and through a mailed questionnaire. The derived findings and discussion lead us towards a clear and big picture of the impact of BISP on consumption, health, and education during the Covid-19.

\section{Covid-19 and BISP:}

When I interact with my respondent's majority of them were respond me that, our husbands were unemployed during the Covid-19, and we were not able to fulfill our basic necessities. The BISP is very beneficial for us to fulfill our basic necessities. Moreover, when I meet with the interviewers I asked her, how many times did you receive BISP income during the Covid-19 and how much? All of them told me: we are receive 4 times, and 12, 000 received.

\section{Relationship between BISP and Consumption:}

I pose a question to my respondents regarding the impacts of BISP on their consumption. One of respondent who told me the BISP income, we consumed on basic necessities, such as bread, cereals, rice, milk, vegetables. Another interviewer told me, my husband was in jail, I have no source of income, to fulfill my basic necessities, only BISP as a source of my basic necessities. One of the respondents who told me about their consumption pattern, we 
consumed BISP income, only on new clothing and shoes. Another respondent is a 59-year-old lady, who told me I consumed my BISP income only my health care.

When I asked to my respondents, the future BISP income affects your current consumption, almost all respondents told me, yes our future BISP income affects our current consumption pattern. For example, our BISP income will be coming after 1 month later, suppose we want to buy clothes, and shoes currently we have no income for it, but we borrowed the money from others, we take agreement with him I will pay your debt when I will be receiving my BISP income.

\section{Relationship between BISP and Health:}

When I talk to different respondents they were responding to me about the BISP effects on health, and their own satisfaction level of health. One of the old women responds to me that I am Diabetes and heart disease, the BISP fulfill my all treatment. If I am talking about my health is good because of BISP.

\section{Relationship between BISP and education:}

One of the best reasons for improving child education is through BISP. One year ago BISP includes the government schools' children in their scheme, the BISP gives at the middle level 1200 rupees per student, while at the matric level the BISP gives 2,000 rupees to per student in each class. It leads to increasing the encouragement of the students. Therefore the parent's attention has been increased to government schools.

I asked a question to my respondents regarding the impacts of BISP on children's education. One of the females responds to me, my husband is a daily wage worker, and he cannot afford my child's education, after receiving the BISP income my child education is very good as compared to the past. It's also improved our children's studies requirement ease to buy their books, bags, school shoes, and clothes etc.

When I talk to different respondents they were responding to me about the BISP effects on children schooling, and their own satisfaction level of children schooling. One of them responds me. If I am talking about my children's education it is good in the side of their books, school shoes uniform as well as pocket money it's good after getting the BISP but on the side of results I'm not satisfy about their results. I'm not educated women and no one more in our home who was guiding them properly. Children were also careless they did not doing homework after back from schooling so no one gives us good results. I am completely not satisfied from my children education.

Another female respondent told me the impact of BISP on children education. She said that BISP fulfill my children's education. Its good effect on the side of religious education, but on the schooling side they are not well but I'm satisfied from their religious education. They are not good in schooling, but it's no need for me just I want improve their education in religious side, and they are going on very well in religious perspective, and she said that I am fully satisfied from their results. 
When I talk with different respondents about the attendance of their children then most of them responding me it is more than $90 \%$ mean to say that it is good. Some of them told me below than $90 \%$.

When I was talking about Attendance with different required respondents they were responding me the attendance of their children's. Mother were telling they are good in attendance 70 to $80 \%$ told me it is more than $85 \%$. Some respondents told me it's below than $80 \%$. So we can easily conclude it students have good attendance. Behind good attendance reason is we have strictly to moving schools not to allow them without any specific reason they have to absent. So almost they are going to school regularly.

\section{CONCLUSION AND POLICY RECOMMENDATION}

The main aim of this empirical study is to examine the Impact of Benazir income support program (BISP) on consumption, health and education during the COVID 19 pandemic. This study used qualitative research approach the data has been collected through structure interviewed and mailed questionnaire. The finding reveled that BISP have positive effect on consumption, health and education.

This empirical study has several recommendations based on research findings: (1) the government should pay the BISP income on monthly basis; (2) the government should increase the BISP income.

Finally, we have a few limitations for this study which will give us direction for future research. We only select Tahsil Matta, district swat region, upcoming studies will use these interviews questions for other regions such as Mardan, Shangla etc. This study only used qualitative research approach, alternative research approach was ignored like quantitative. We only analyzed the impact of BISP on consumption, health and education, and ignored the impact of BISP on poverty, women empowerment, unemployment etc.

\section{REFERENCES}

1. World Bank (2010). Poverty in Pakistan: vulnerabilities, social gap and rural dynamics. Washington D.C.

2. DFID lauds BISP performance by giving it overall 'A' rating". Available at: www.thenews. com.pk (accessed 12 June 2021).

3. $\operatorname{BISP}(2021$, Feb 28). Vision \& Mission. Retrieved from Benazir Income Support Programme - Government of Pakistan. Available at: https://bisp.gov.pk/overview/\#: :text=The\%20 Benazir\%20Income \% 20 Support $\% 20$ Program, effects $\% 20$ of $\% 20$ slow $\% 20$ economic\%20growth (accessed 12 June 2021).

4. Cheema, I., Farhat, M., Hunt, S., Javeed, S., Pellerano, L., \& O'Leary, S. (2014). Benazir income support programme. 
5. Khan (2021). Evaluation: Benazir Income Support Program (BISP). Available at: https:// www.researchgate.net/publication/349685025_Evaluation_Benazir_Income_Support_ Program_BISP/references\#fullTextFileContent (accessed 12 June 2021).

6. Cheema, I., Hunt, S., Javeed, S., Lone, T., O'leary, S. (2016). Benazir Income Support Programme: final impact evaluation report. Oxford Policy Management limited, UK.

7. Naseer, Z., Hu, H., Yaseen, M., \& Tariq, M. (2021). Rural women empowerment through social protection programs: A case of Benazir income support programme in Punjab, Pakistan. Journal of the Saudi Society of Agricultural Sciences, 20(2), 67-74.

8. World Bank (2001). Engendering Development: Through Gender Equality in Rights. Oxford University Press, Resources and Voices.

9. Akram, N., Hamid, A., Bashir, S. (2011). Gender differentials in education and their impact on economic growth of Pakistan. J. Business Economics, 3 (1), 102-122.

10. Iqbal, T., Padda, I. U. H., \& Farooq, S. (2020). Unconditional Cash Transfers and Women Empowerment: The Case of Benazir Income Support Programme (BISP) in Pakistan. Journal of Business and Social Review in Emerging Economies, 6(2), 401-418.

11. Waqas, M. \& Torre A. (2020). Political favouritism and social conflict: a case study of the Benazir Income Support Programme (BISP) in Pakistan. Area Development and Policy, 5 (3), 334-349, DOI: 10.1080/23792949.2019.1623055

12. Besley, T., \& Burgess, R. (2003). Halving global poverty. Journal of economic perspectives, 17(3), 3-22.

13. Ravallion, M., Chen, S., \& Sangraula, P. (2007). New evidence on the urbanization of global poverty. Population and development review, 33(4), 667-701.

14. Fiszbein, A., \& Schady, N. R. (2009). Conditional cash transfers: reducing present and future poverty. World Bank Publications.

15. Liu, Q. Q., Yu, M., \& Wang, X. L. (2015). Poverty reduction within the framework of SDGs and Post-2015 Development Agenda. Advances in Climate Change Research, 6(1), 67-73.

16. Narayan-Parker, D. (2006). Measuring empowerment: Cross-disciplinary perspectives. New Delhi: Oxford University Press.

17. Smith, S. (2014). Limitations to equality: Gender stereotypes and social change. Juncture, 21(2), 144-150. DOI: 10.1111/j.2050-5876.2014.00795.x

18. Inglehart, R., \& Norris, P. (2003). Rising tide: Gender equality and cultural change around the world. New York: Cambridge University Press.

19. Gary, S. B. (1991). A Treatise on the Family (enlarged edition). London: Harvard University Press. Gazdar, $\mathrm{H}$.

20. Banzir Income Support Program (BISP) (March 2017). An in-depth interview with two officials. Multan, Pakistan.

21. Waqas M., \& Awan, M. S. (2019). Do Cash Transfers Effect Women Empowerment? Evidence from Benazir Income Support Program of Pakistan. Women's Studies, 48 (7), 777-792. DOI: 10.1080/00497878.2019.1666007

22. Waqas, M. \& Awan, M. S. (2018). Access to better health? The impact of the Benazir Income Support Programme in Pakistan. Asia Pacific Journal of Public Administration, 40 (1), 74-81. DOI: 10.1080/23276665.2018.1448505 
23. Mumtaz Z. \& Whiteford, P. (2017). Social safety nets in the development of a welfare system in Pakistan: an analysis of the Benazir Income Support Programme. Asia Pacific Journal of Public Administration, 39 (1), 16-38. DOI: 10.1080/23276665.2017.1290902

\section{Appendix 1 Interview Question}

Q.1. Name (Optional)

Q.2. Age

Q.3. Family structure

Q.4. Number of family members including children

Q.5. Total family income

Q.6. Are BISP Beneficiary?

Q.7. How many times did you receive BISP income?

Q.8. How much time to take received BISP income?

\section{BISP, lockdown, health, and Consumption:}

Q.9. Are your husband or family member unemployed during a lockdown?

Q.10. How are the BISP affect your consumption patterns during a Covid-19?

Q.11. How you consumed your BISP income?

Q.12. Is BISP fulfill your consumption pattern during a lockdown.

Q.13. Is upcoming BISP income affect your current consumption pattern?

Q.14. Are you facing any chronic disease?

Q.15. How much does BISP improve your chronic disease?

Q.16. Are BISP improve your health care

Q.17. Is BISP affect your child's education?

Q.18. How does BISP affect enrolment of child schooling?

Q.19. How does BISP affect the academic performance of child schooling?

Q.20. Any recommendation from the Government of Pakistan about BISP.

\section{INFORMATION ABOUT THE AUTHOR}

ljaz Uddin (Pakistan, Mardan) - PhD Scholar, Department of Economics. The Abdul Wali Khan University Mardan (AWKUM). E-mail. Ijazuddin01@gmail.com. ORCID ID: 00000002-7231-109X

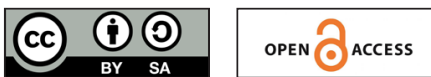

Available: https://statecounsellor.wordpress.com/2021/11/28/uddin-4/

Received: Mar 15, 2021 | Accepted: Oct 5, 2021 | Published: Dec 1, 2021

Editor: Santosh K. Behera. PhD. Sidho-Kanho-Birsha University, INDIA

Copyright: ( 2021 Uddin, I. This is an open access article distributed under the terms of the Creative Commons Attribution License, which permits unrestricted use, distribution, and reproduction in any medium, provided the original author and source are credited.

Competing interests: The authors have declared that no competing interests exist. 